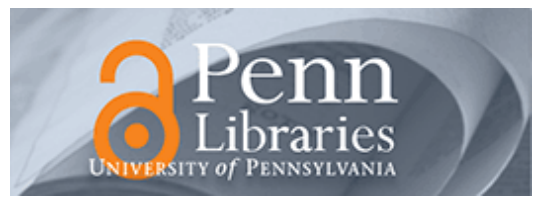

University of Pennsylvania

ScholarlyCommons

\title{
No Child Left Behind: Repealing and “Unpeeling” Federal Language Education Policy in the United States
}

Bruce A. Evans

Nancy H. Hornberger

University of Pennsylvania, nancyh@gse.upenn.edu

Follow this and additional works at: https://repository.upenn.edu/gse_pubs

Part of the Bilingual, Multilingual, and Multicultural Education Commons, Curriculum and Instruction Commons, Education Policy Commons, and the Elementary and Middle and Secondary Education Administration Commons

\section{Recommended Citation}

Evans, B. A., \& Hornberger, N. H. (2005). No Child Left Behind: Repealing and "Unpeeling" Federal Language Education Policy in the United States. Language Policy, 4 (1), 87-106. http://dx.doi.org/10.1007/ s10993-004-6566-2

This paper is posted at ScholarlyCommons. https://repository.upenn.edu/gse_pubs/317

For more information, please contact repository@pobox.upenn.edu. 


\title{
No Child Left Behind: Repealing and “Unpeeling” Federal Language Education Policy in the United States
}

\author{
Abstract \\ For more than three decades U.S. language education policy was realized through the Bilingual Education \\ Act (BEA), enacted in 1968 to meet the educational needs of language minority students. The BEA \\ emphasized bilingual education and provided options for the development of students' native language \\ as well as their English language proficiency and academic achievement. In 2002 the BEA was replaced \\ with the English Language Acquisition, Language Enhancement, and Academic Achievement Act. Current \\ policy implicitly repeals the $B E A$ and emphasizes the need for schools to quickly develop students' \\ English language proficiency and move them to English only classrooms. Drawing on Ricento and \\ Hornberger's (1996) "onion metaphor" for the multi-layered nature of language planning and policy, this \\ paper considers the potential impact changes in language education policy may have on programs and \\ practices for language minority students. A summary of interview responses from a small sample of \\ Southern Oregon educators adds an on the ground perspective.

\section{Keywords} \\ No Child Left Behind, bilingual education, language planning orientation, scientifically based research, \\ onion metaphor, teachers' understandings, language minority education

\section{Disciplines} \\ Bilingual, Multilingual, and Multicultural Education | Curriculum and Instruction | Education | Education \\ Policy | Elementary and Middle and Secondary Education Administration
}


Evans, B., \& Hornberger, N. (2005). No Child Left Behind: Repealing and "Unpeeling" Federal Language Education Policy in the United States. Language Policy, 4(1), 87-106. http://dx.doi.org/10.1007/s10993-004-6566-2

Running Head: Unpeeling U.S. federal language education policy

Title: No Child Left Behind: Repealing and "Unpeeling" Federal Language Education Policy in the United States

Authors: Bruce A. Evans \& Nancy H. Hornberger

Bruce A. Evans

Southern Oregon University

1250 Siskiyou Blvd., Ashland, OR, 97520

Tel: 541-512-1614

Fax: 541-552-6287

Email: evansb@sou.edu

Nancy H. Hornberger

University of Pennsylvania

3700 Walnut Street, Philadelphia, PA 19104-6216

Tel: 215-898-7957

Fax: 215-898-7957

nancyh@gse.upenn.edu 
ABSTRACT. For more than three decades U.S. language education policy was realized through the Bilingual Education Act (BEA), enacted in 1968 to meet the educational needs of language minority students. The BEA emphasized bilingual education and provided options for the development of students' native language as well as their English language proficiency and academic achievement. In 2002 the $B E A$ was replaced with the English Language Acquisition, Language Enhancement, and Academic Achievement Act. Current policy implicitly repeals the BEA and emphasizes the need for schools to quickly develop students' English language proficiency and move them to English only classrooms. Drawing on Ricento and Hornberger's (1996) "onion metaphor" for the multi-layered nature of language planning and policy, this paper considers the potential impact changes in language education policy may have on programs and practices for language minority students. A summary of interview responses from a small sample of Southern Oregon educators adds an on the ground perspective.

KEY WORDS: $\quad$ No Child Left Behind, bilingual education, language planning orientation, scientifically based research, onion metaphor, teachers' understandings, language minority education

\section{LIST OF ABBREVIATIONS}

BEA Bilingual Education Act

ESEA Elementary and Secondary Education Act

IASA Improving America's Schools Act

LEP Limited English Proficient

NCLB No Child Left Behind

OBEMLA Office of Bilingual Education and Minority Language Affairs 
Unpeeling U.S. federal language education policy

OELALEAALEPS Office of English Language Acquisition, Language Enhancement, and Academic Achievement for Limited-English-Proficient Students 
INTRODUCTION

On January 8, 2002, No Child Left Behind (NCLB) was signed into law, replacing the Improving America's Schools Act of 1994 as U.S. federal education policy. It. NCLB is the most recent reauthorization ${ }^{1}$ of the Elementary and Secondary Education Act (ESEA) which Congress enacted in 1965 to address the educational challenges of children living in poverty. In 1968 the ESEA was amended to include Title VII, the Bilingual Education Act,designed to address the needs of students with limited English proficiency. It provided funds directly to local school districts and schools through competitive grants.

Though titled the Bilingual Education Act (BEA) from its inception, support for use of an English language learner's ${ }^{2}$ native language for instructional purposes in federally funded programs varied over the life of the act. Through several revisions and reauthorizations that varied in specific provisions, Title VII nevertheless consistently made space for bilingual education, in one form or another. The last reauthorization of the BEA in 1994 removed a previous three year limit on the amount of time a student could be in a Title VII program and gave preference to programs that sought to develop students' native-language skills while simultaneously fostering English language proficiency. This resulted in the growth of a number of additive programs for students with limited English proficiency including late-exit 'developmental' bilingual programs that feature a more gradual transition to English - typically four to five years - and twoway bilingual programs, also known as dual language immersion programs, that include

\footnotetext{
${ }^{1}$ As with most U.S. federal laws, the Elementary and Secondary Education Act requires reauthorization to be continued.
} 
English-speaking children learning a second language alongside language minority children learning English (Crawford 2002b).

All of this changed dramatically with the introduction of NCLB in 2002. Current policy implicitly repeals the BEA and emphasizes the need for schools to quickly develop students' English language proficiency and move them to English only classrooms. In what follows, we contemplate the implications of this policy change for language minority students in the United States. Drawing on Ricento and Hornberger's (1996) "onion metaphor" for the multi-layered nature of language planning and policy, we allude to potential effects at the national, institutional, and interpersonal levels, basing our speculations on both the research literature and interviews with a small sample of Southern Oregon educators for an on the ground perspective.

\section{A Change in U.S. Language Education Policy}

With the 2002 reauthorization of the ESEA, a number of revisions have resulted in significant policy and program changes for English language learners and bilingual education. The new act is Title III, Language Instruction for Limited English Proficient and Immigrant Students. As with Title VII of the Improving America's Schools Act of 1994 (IASA), it sets as goals high academic achievement and attainment of English language proficiency by students with limited English proficiency. The 1994 and 2002 acts differ significantly, though, in their approaches to achieving these goals:

1. Funding: Through NCLB formula grants to states, all schools with "limited English proficient" (LEP) students will receive funds for services for those students. However,

\footnotetext{
${ }^{2}$ The term English language learner has in recent years become the preferred term among educators rather than referring to students as "limited English proficient" (LEP) because of the negative connotations of the
} 
under the current formula, funds allotted to the states for educational service amount to less than $\$ 150$ per student (Crawford 2002b: para 12). Under IASA, school districts and schools received funding directly through competitive grants. Amounts varied and fewer schools received federal funds, but the amount of money per student tended to be proportionately greater.

2. Role of a learner's native language: Under IASA, a learner's native language was acknowledged as playing an important role in facilitating English language development and allowing students to keep pace academically while developing adequate English language proficiency to do grade level work in English. In NCLB, English language development is taken as the sine qua non of academic achievement and a child's native language is assigned less of a facilitative role in promoting English language development. Indeed, it may be viewed as a crutch in subject area study that prevents children from making adequate progress toward English language proficiency.

3. Length of time necessary to develop English language proficiency: By not prescribing the length of time a child may receive English language instructional services or participate in bilingual education, IASA allowed for the varying lengths of time children take to attain English language proficiency. It also acknowledged that children may take several years to develop a level of proficiency necessary to learn and achieve academically in English. NCLB takes the view that children can generally develop a sufficient level of English language proficiency to enable them to meet the same academic standards in English only classes as native English speaking students in three or fewer years.

latter term. We follow this usage, except when quoting or summarizing documents that use LEP. 
4. Activities: IASA set out several broad categories of authorized program types and activities for which Title VII funds could be used: comprehensive bilingual, ESL, and other instructional programs for students with limited English proficiency; providing inservice and other training for faculty, staff and other personnel; curriculum and materials development; and family education programs. NCLB lists a number of required activities as well as authorized activities. A qualifying requirement of NCLB activities is that they be based on "scientifically based research." Required activities emphasize increasing LEP students' English proficiency and academic achievement in core academic subjects. Authorized program types and activities basically mirror those in Title VII except that bilingual education activities are not among them.

5. Accountability and Sanctions: Under IASA, only those districts and schools that received grants were required to meet federally mandated program requirements. Under NCLB, all schools and school districts with LEP students will have to meet federally mandated requirements. Sanctions under IASA amounted to loss of funding. Under NCLB, in addition to losing funding, schools not meeting federal accountability requirements may be required to reorganize, remove personnel, and provide funds for students to attend private programs.

ANALYZING Language PlanNing AND Policy:

The Onion and National Language Education Policy in the US

With a much revised ESEA under No Child Left Behind, how much improvement can be expected in English language learners' academic achievement and their increased English language proficiency? Ricento and Hornberger (1996) have proposed an onion metaphor for conceptualizing the interactions between agents in language planning, policy 
formation and implementation, which may shed some light on probable outcomes. In this schema, planning and policy decisions are made and realized at a number of levels which make up the layers of the onion. In their words:

At the outer layers of the onion are the broad language policy objectives articulated in legislation or high court rulings at the national level, which may then be operationalized in regulations and guidelines; these guidelines are then interpreted and implemented in institutional settings, which are composed of diverse, situated contexts (e.g. schools, businesses, government offices); in each of these contexts, individuals from diverse backgrounds, experiences, and communities interact. At each layer (national, institutional, interpersonal), characteristic patterns of discourse, reflecting goals, values, and institutional or personal identities, obtain. [These] discourses are never neutral. They are always structured by ideologies.

As it moves from one layer to the next, the legislation, judicial decree, or policy guideline is interpreted and modified. Legislation at one or another government level may not be funded; it may even be unenforceable. In other instances, guidelines proposed in one administration may not be enforced by those that follow. Politics affects language planning processes at all levels of analysis. (excerpted from Ricento \& Hornberger, 1996: 409-411).

The following sections seek to "unpeel" the potential effects of NCLB on the education of language minority students, considered at national, institutional, and interpersonal levels. In particular, we speculate on policy discourses and their underlying ideologies at the national level, issues of school accountability and scientifically-based research at the institutional level, and perceptions of both ESL and mainstream teachers at the interpersonal level. Our considerations are based on our reading of the policies and the 
research literature and on interviews with a small sample of Southern Oregon educators for an on the ground perspective.

\section{National Level: Policy Discourses and Their Underlying Ideologies}

The recent reauthorization of the ESEA coincided with a change of administrations. With a new president came a change in philosophy toward public education, notably a focus on school accountability. More specifically, acomparison of the 1994 and 2002 federal language education policies (IASA Title VII and NCLB Title III) suggests two opposing implicit foundational ideologies or language planning orientations. Ruiz (1984) defines orientations as attitudes toward languages and their speakers and toward language and the roles language plays in society.and proposes three orientations commonly found in language planning in the United States and elsewhere: language as problem, language as right, and language as resource. The discourse of Title VII suggests a language as resource orientation and possibly a language as right orientation. The title, the Bilingual Education Act, indicates a role for a child's native language in developing English language proficiency and achieving academic success. Statements in the act concern the value of "multilingual skills" to the nation and the use of a child's native language and culture in "contributing to academic achievement and learning English." (Improving America's Schools Act of 1994, 7 U.S.C. $§ 7102)$.

The discourse of Title III, however, reflects a language as problem orientation and certainly provides little evidence of either a language as resource or a language as right orientation. After three decades as the Bilingual Education Act, the title of the section concerned with the education of children with limited English proficiency has been changed to the English Language Acquisition, Language Enhancement, and 
Academic Achievement Act. In addition, the term "bilingual" has been expunged from the law. The term only appears in reference to changing the Office of Bilingual Education and Minority Language Affairs (OBEMLA) to the Office of English Language Acquisition, Language Enhancement, and Academic Achievement for Limited-EnglishProficient Students (OELALEAALEPS) and its director's title (No Child Left Behind Act of 2001, 10 U.S.C. $§ 1072$ ). Title III contains no statement concerning the value of multilingualism to the nation or to a child's English language development and academic achievement. The required and authorized activities under Title III emphasize the development of children's English language proficiency, but make no mention of a role for a child's native language in that process (No Child Left Behind Act of 2001, 7 U.S.C. § $3115)$.

Ironically, this U.S. policy shift away from a view of multilingualism as resource and toward the imposition of monolingual English only instruction in U.S. schools occurs in a global context in which both multilingualism and multilingual language policies are as much in evidence as they ever were, if not more so. Language policy scholars increasingly argue for ecological approaches to language policy, approaches which recognize that no one language and its speakers exist in isolation from other languages and their speakers. ${ }^{3}$ In a world that is simultaneously coming together as a global society while it splinters apart into ever smaller ethnically-defined pieces, where population and information flows inevitably bring global and local languages into contact in everevolving combinations, an ecological approach would suggest that any language

\footnotetext{
${ }^{3}$ Three themes of the ecology of language are that languages "(1) live and evolve in an eco-system along with other languages (language evolution), (2) interact with their sociopolitical, economic, and cultural environments (language environment), and (3) become endangered if there is inadequate environmental support for them vis-à-vis other languages in the eco-system (language endangerment)" (Hornberger 2002: 35-36).
} 
education policy must take into account all the languages in the eco-system if in fact the goal is to offer education to all. No Child Left Behind ignores this imperative.

\section{Institutional Level: School Accountability and Scientifically-Based Research}

Institutions are

relatively permanent socially constituted systems by which and through which individuals and communities gain identity, transmit cultural values and attend to primary social needs. Examples are schools, organized religion, the media, civic and other private and publicly subsidized organizations (libraries, musical organizations), and the business community. (Ricento \& Hornberger 1996: 415) Attitudes toward languages and their speakers are deeply embedded in institutional structures and practices and these attitudes are transmitted to and influence agents and processes in other layers. For example, "Bilingual education has often been opposed in the U.S. because, among other reasons, Americans have been socialized to believe that the unity and cultural integrity of the U.S. cannot abide cultural, including linguistic, pluralism" (Ricento \& Hornberger 1996: 416). Schiffman (1996) terms these kinds of belief systems, attitudes, and ways of thinking about language "linguistic culture" and argues that language policy is ultimately grounded in linguistic culture.

No Child Left Behind has been supported, initially at least, by many agents at the institutional level. In the lead-up to the act being signed into law and since, it has been touted by proponents as the savior for the much maligned public education system. Under the accountability requirements of the law, schools would have to ensure that all students meet high educational standards and that all LEP students would develop high levels of English language proficiency. The accountability requirements appeal to many who are convinced that public education is a large bureaucratic system that wastes money 
and does little to educate the nation's children. Business organizations, religious groups, and numerous think-tanks have praised NCLB. The media, by and large, has uncritically reported its goals and proposed benefits. The philosophical and policy changes related to English language education have probably coincided with beliefs and attitudes about language acquisition held by many educational administrators at the state and local levels.School administrators, for example, have been skeptical about the number of years typically necessary (5-7) for English language learners to become proficient in academic English as reported in the professional literature. Many policy makers as well insist there must be a faster way to develop learners' English (Thomas \& Collier 1997: 33).

Educators closely tied to the education of language minority students are likely to see one beneficial outcome of the accountability requirements. Students' achievement under NCLB is now disaggregated according to subgroup, e.g. students with special needs and those with limited English proficiency. If the required percentage of students in one of the subgroups doesn't attain the standards set for all students by NCLB, the whole school becomes classified as "in need of improvement." If a school is classified as in need of improvement more than two consecutive years, it is sanctioned. With each subsequent year, the sanctions get more severe including paying for students to get outside help, sending students to other schools, removal of personnel and ultimately reorganization of the school. With the threat of the "in need of improvement" classification hanging over their heads, teachers and administrators who haven't been concerned with the needs of English language learners will now be concerned. Where in the past funds intended for LEP students may have been added to the general fund, now those funds are to be devoted to programs for those students.

By and large, though, educators closely tied to the education of language minority students and educational researchers are not likely to receive No Child Left Behind with open arms. Principally, there is a disconnect between NCLB and the assumptions upon 
which it is based and findings from research and educational experience that serve as the theoretical and empirical foundations for university teacher preparation programs, state education plans and programs, and local school district and school instructional programs and practices.

In conjunction with a language as problem orientation, NCLB Title III employs a myopically monolingual view of English language learners' bilingual and biliterate development of language and literacy skills. Title III provisions appear to be based on the assumption that with only three years of special language services English can be acquired at levels that will enable students with limited English proficiency to perform academically on par with their native English speaking peers (No Child Left Behind Act of 2001, 7 U.S.C. $§ 3113 \&$ 3122). However, to do cognitively demanding, context disembedded mainstream academic work, students need to attain advanced levels of English language proficiency (Cummins 1984, 1992; Krashen \& McQuillan 1999). Research on the amount of time it takes to acquire a second language indicates that a child may develop basic interpersonal communication proficiency in a second language in two or three years, though some children will take longer (Cummins 1981; Wong Fillmore 1991). However, the level of language proficiency necessary to do the type of academic work required by NCLB takes much longer to develop, typically more than five years (Cummins 1979; Thomas \& Collier 1995), and as many as ten years when children are schooled exclusively in the second language (Collier 1995).

Furthermore, NCLB acknowledges little or no role for a child's first language in the acquisition of English or in academic achievement. The few statements in the act concerning a child's native language are framed in terms of developing "English proficiency and, to the extent possible, proficiency in their native language" (No Child Left Behind Act of 2001, 7 U.S.C. $§ 3211,2$, A). Research on the efficacy of bilingual education, though, indicates that instruction in learners' native language has a number of 
benefits. Use of learners' native language in the classroom enables English language learners to participate more fully in learning and social activities. At a minimum, English language learners in bilingual classrooms acquire English language skills equivalent to those attained by similar children in English-only programs (Cummins 1981; Ramirez, Yuen \& Ramey, 1991), and in other cases attain higher levels of English language proficiency than students in all-English programs (Mortensen 1984).

In additive bilingual education contexts, in which the continued development of English language learners' native language is a program goal, students' English language development exceeds those of peers in English-only classrooms and those who receive ESL support but whose native language isn't supported. Students in these developmental bilingual programs eventually achieve on level academically in English with their native English speaking peers (Burnham-Massey \& Pina, 1990; Collier 1992; de la Garza \& Medina 1985 [cited in Krashen, 1999]; Thomas \& Collier 1996). Students in two-way bilingual programs typically advance to high levels of English language proficiency and literacy and exceed many native English speaking students academically. This holds true for English speaking students who are learning through two languages as well (Collier 1992; Thomas \& Collier 1996). Knowledge and skills acquired and developed through the first language are available to the second language (Cummins 1984, 1992); however, if students do not reach a certain threshold in their first language they may experience cognitive difficulties in the second language (Cummins 1976; Thomas \& Collier 1996; Toukomaa \& Skutnabb-Kangas 1977 [cited in Baker 1996: 148]). Indeed, the more their learning contexts, contents, and media allow language learners to draw from across the whole gamut of their languages and literacies, the greater are the chances for their full biliterate development and expression (Hornberger 2003). 
Anadditional problem area from an institutional perspective concerns the notion of'scientifically based research' that appears throughout No Child Left Behind. Ironically, considering the NCLB's lack of regard for research on bilingualism and biliteracy such as that described above, the legislation stipulates that federally funded programs and practices must be grounded in scientifically based research, including instructional methodologies, classroom materials, academic assessments, teacher training, and remedial tutoring (Crawford 2002a). The crux of the matter is that what qualifies as scientific research is being redefined by the U.S. Department of Education. In the preface to its discussion on scientific research in its Strategic Plan for 2002-2007, the Department of Education characterizes currently accepted educational research as not meeting the standards for science.

Unlike medicine, agriculture, and industrial production, the field of education operates largely on the basis of ideology and professional consensus. As such, it is subject to fads and is incapable of the cumulative progress that follows from the application of the scientific method and from the systematic collection and use of objective information in policy making. (U.S. Department of Education 2002: 59)

Recent educational practices have also been compared to "medieval medicine" and current knowledge in education has been characterized as "superstition" by officials of the U.S. Office of Educational Research and Improvement (Erickson \& Gutierrez 2002: 22).

Scientifically based research, as defined in NCLB, is research that "applied rigorous, systematic, and objective procedures to obtain valid knowledge." It includes research that

employs systematic, empirical methods that draw on observation or experimentation; involves rigorous data analyses that are adequate to test the stated hypotheses and justify the general conclusions drawn; relies on 
measurements or observational methods that provide valid data across evaluators and observers and across multiple measurements and observations; and has been accepted by peer-reviewed journal or approval by a panel of independent experts through a comparably rigorous, objective, and scientific review. (No Child Left Behind Act of 2001, 7 U.S.C. § 1208))

Another essential feature of scientifically based research as defined by the Department of Education, is random assignment of sample subjects ("A closer look at scientifically based research" 2004: para 7).

This definition of scientific research is out of alignment with that of a number of educational researchers. The law fails to recognize the unique nature of educational research which must contend with complexities of context, the interactions among participants and a range of intervening factors, and the changing nature of the social environment that invalidates or renders irrelevant solid scientific findings from the previous decade (Berliner 2002: 18). The emphasis on causal analysis by means of experiment in order to determine effective practices is another concern. NCLB does notexclude funding of qualitative research and the Department of Education states that such research is allowed under the act, but many researchers would argue that qualitative research is more than merely allowable; it is essential if causal analysis is to succeed. A logical and empirically prior question to "Did it work?" is "What was the 'it'?" - "What was the 'treatment' as actually delivered?" Educational treatments are situated and dynamically interactive. They are locally constructed social ways of life involving continual monitoring and mutual adjustment among persons, not relatively replicable entities like chemical compounds or surgical procedures or hybrid seed corn or manufactured airplane wings. (Erickson \& Gutiérrez 2002: 21) 
There is also concern over premature conclusions about 'what works' in the short term without careful considerations of unexpected outcomes and side effects.

Will our current desperate attempts to discover 'what works' to raise standardized test scores in the short run have analogous affects [to the medical experience with thalidomide $\left.{ }^{4}\right]$ on our children and teachers in school, effects that are only apparent after much damage has been done? (Erickson \& Gutiérrez 2002: 23).

From a legal perspective, there are constraints on the use of random assignment of subjects for educational research. Federal guidelines, based on the Lau v. Nichols (U.S. Supreme Court 1974) decision of the U.S. Supreme Court, require that all English language learners receive some form of special assistance. This legal constraint makes it difficult, if not unrealistic, for a school system to create a laboratory-like control group that would not receive the special assistance. "At best, one might find a comparison group that received an alternative form of special assistance, but even this alternative is not easily carried out in practice." (Thomas \& Collier 1997: 20).

There are also ethical constraints on true random assignments of children in educational studies.

If the researcher knows, or even suspects, that one treatment is less effective than another, he or she faces the ethical dilemma of being forced to randomly assign students to a program alternative that is likely to produce less achievement than an alternative known to be more effective. (Thomas \& Collier 1997: 20)

With an official attitude toward previous educational research as "subject to fads" and likened to "superstition" and the No Child Left Behind definition of scientific research, much of the foundational research related to language education and the

\footnotetext{
${ }^{4}$ A non-barbiturate hypnotic, thalidomide was originally prescribed after 1956 to prevent morning sickness in pregnant women and to help them sleep through the night. It prevented the morning sickness but caused deformities in the fetus. The latter effects were only discovered after the babies were born, and it took years
} 
programs and practices that are based on that research could be rejected. "While such a requirement sounds reasonable in theory, the term remains poorly defined by law and thus vulnerable to abuse. The key question is: who will determine what is 'scientific' ?" (Crawford 2002b: para 8).

Analysis of No Child Left Behind suggests that the philosophy and content of the act are in many ways in conflict with the theoretical and empirical foundations of many of the agents that comprise the educational institutions. These conflicts concern issues of the amount of time it takes to acquire sufficient English language proficiency to enable English language learners to achieve at grade level, the role of a child's native language in English language development and academic achievement, and what constitutes scientific research to serve as a foundation for language education programs and practices.

\section{Interpersonal Level: ESL and Mainstream Teachers' Roles and Perceptions}

Within the hierarchy of language policy, the practitioner is often an afterthought. Their role, as widely perceived, is to implement policy decided upon by 'experts' in the government, board of education, or central school administration. Ricento and Hornberger, in contrast, claim that "educational and social change and institutional transformation, especially in decentralized societies, often begin with the grass roots" (1996: 417). As teachers interpret and modify received policies, they are, in fact, primary language policymakers.

The discourses of schools, communities and states reinforce unstated beliefs which teachers may come to hold and which may or may not reflect explicit policies (e.g. English only in ESL classrooms). At the same time, there may be tension between what

to trace the cause of the deformities back to the mothers' use of thalidomide. (Erickson \& Gutierrez 2002: $23)$. 
the practitioner believes to be in the best interest of students and societal, community and school beliefs or policy. For example, as Ricento \& Hornberger point out, bilingual education has not generally been supported in the Unites States. However, many English language teaching professionals, through training and experience, have come to believe that bilingual education is an effective, if not the most effective approach for facilitating students' English language development while guaranteeing their cognitive development and academic achievement.

At this level, perceptions of NCLB need to be distinguished between those of ESL teachers and those of mainstream teachers. ${ }^{5}$ In U. S. schools, a number of program types are in place for meeting the needs of language minority students. Schools with large numbers of English language learners may have bilingual education classes and/or sheltered-English classes. In sheltered-English classes, the students are all English language learners and academic content is taught in English using instructional methods designed for English language learners. In schools with an insufficient number of students with limited English proficiency to warrant entire classes for them, there is commonly an ESL teacher who works with English language learners. These students are in mainstream classrooms most of the day and are pulled out to meet with the ESL teacher or for an ESL class.

As referenced in the previous section on the institutional level, all teachers are now responsible for the education of students with limited English proficiency. In the past, if English language learners didn't develop high levels of English proficiency or didn't do well academically, mainstream teachers were not directly held responsible. Now if a sufficient number of English language learners in their school fail to reach the

\footnotetext{
${ }^{5}$ Mainstream teachers typically have no training in teaching English language learners. At the elementary level mainstream teachers are in multi-subjects classrooms. At the secondary level they are subject-area teachers.
} 
required standards, everyone in the school is held accountable. For many teachers, then, there is an added responsibility of improving English language learners' English proficiency and ensuring they do as well academically as native English speaking students. Given the additional responsibility, mainstream teachers are not likely to have a favorable view of NCLB as it pertains to English language learners.

ESL teachers are likely to have conflicting thoughts and attitudes about No Child Left Behind. On one hand the added attention paid to English language learners, the added support that ESL teachers may receive and the additional funds, however small, to be dedicated to services for English language learners may be seen as beneficial. On the other hand, ESL teachers may take issue with the philosophy underlying NCLB and the methodological requirements and constraints of the law. Given their university preservice training, in-service training, and experience, their understanding of what constitutes effective education for English language learners could be in conflict with federal language education policy in the form of NCLB.

To inquire into on the ground perspectives on NCLB's federal language education policy,the first author (Evans) interviewed several educators in one U.S. geographical area,, Southern Oregon. While mostly rural, Southern Oregon is a region in transition.having experienced significant growth over the past decade. Included in that growth are increasing numbers of people, with varying degrees of English language proficiency, who work in the orchards, restaurants, and the various businesses that cater to the ever- growing tourist industry, based largely on the presence of Crater LakeNational Park and of Interstate Highway 5 toCanada . Area schools have experienced a marked increase in language minority students, primarily Spanish speakers, with several schools having English language learner student populations of around 15\% or more. While the appearance of English language learners is a new phenomenon for some schools and districts, in others English language learners have been a constant for 
several decades. With these characteristics, southern Oregon is fairly representative of many areas of the United States.

Seven elementary school teachers, two school district ESL coordinators, and two regional migrant education/ESL personnel were interviewed to get a cross-section of practitioner perspectives. Participants were selected for their working contexts, experience and positions. All were known to Evans through an educators' reading circle or through cooperation in practicum supervision. Five of the teachers teach in established two-way bilingual programs in two schools in the same school district, two in one school and three in another. The other two teachers are ESL teachers in schools that until recently have had few English language learners. Both of the ESL coordinators, whose responsibilities include teaching ESL part-time, are in school districts that until recently have had small numbers of English language learners. , buthave experienced noticeable increases of students in need of special language services over the past 2 - 3 years. . The other two educators interviewed are the department coordinator and the elementary education specialist in the Migrant Education/ESL Department of the Southern Oregon Education Service District ${ }^{6}$, they provide training and other types of support to schools and teachers. All of the participants have had ten or more years of experience in teaching and working with English language learners. The participating educators were asked several questions in informal interviews (Appendix I). Except in the case of the two teachers from the same elementary school, they were interviewed individually. Teacher interviews were recorded as field notes while the interviews with the ESL coordinators and Migrant Education/ESL personnel were audio taped and transcribed. A summary of the participants' responses follows.

\footnotetext{
${ }^{6}$ Public school districts in Oregon are organized into 20 education service districts that provide a range of services to member districts. The Southern Oregon Education Service District is made up of thirteen school districts covering three southwest counties.
} 
The ESL coordinators and the Migrant Education/ESL staff were happy about the increased attention paid to English language learners in the area's schools. Money that previously would have gone into the general fund is now dedicated to materials and services for students with limited English proficiency, and ESL teachers and associated personnel are receiving more support. District superintendents and school principals have become more concerned about students' increased English proficiency and academic achievement, and are supporting professional development activities, unseen in the past, related to teaching English language learners.

The teachers provided mixed responses. Those from the two schools with long established two-way bilingual programs replied that they have not changed their practices much, if at all, and don't expect to. They have gotten good results and believe they are doing the right thing. They are using the funds they received for additional materials, including those in students' first language, and for after school programs. Students who come out of their programs attain high levels of English language proficiency and, on average, do as well academically as their native English speaking peers in middle school and high school..

The ESL coordinators and teachers in the schools that have recently experienced an increase in the numbers of English language learners expressed less certainty. They were generally confused about how much money they were to receive and what they could spend their funds on. As the numbers of English language learners have not reached a threshold number to warrant establishing bilingual education or shelteredEnglish courses, they do notanticipate program changes. The increased support they have received from the other faculty members and the school administration is a benefit. Where they anticipate changes is in providing training for non-ESL teachers and purchasing materials. However, until they receive more guidance, they are unsure of what will happen. 
All participants interviewed expressed concern about the change in tone from what we have characterized as a language as resource or a language as right orientation to one that seems to be a language as problem view.In addition, as they all have had a decade or more of experience and have witnessed several administrations and policy changes they are taking a wait-and-see approach. As one participant said, "In a couple of years we'll have another administration, and administration change, and then we will start all over again."

\section{CONCLUSION}

Given its title and proposed outcomes, No Child Left Behind has received popular support. Against the backdrop of terrorist acts, Americans feel threatened by the outside world and immigration has become even more of an emotional issue. Perceptions of language education are tied to this, including widely held misperceptions that immigrants do notwant to learn English, especially those from Mexico and Central America, and that children with limited English proficiency are not learning English in school. Among educators and institutions responsible for and associated with the education of language minority students, however, there may be less support of the legislation and its underlying ideology.

NCLB claims to provide states, schools, and teachers greater flexibility than the earlier Elementary and Secondary Education Act. However, mainstream teachers who are now to be held accountable for English language learners' attaining high levels of English language proficiency and academic achievement may resist some of the top-down prescriptions that accompany the funding. Omissions and numerous requirements of the law seem to conflict with language educators' understandings of conditions that promote second language acquisition, the development of high levels of English proficiency and academic achievement on level with native English speaking students. If teachers feel 
they are already "doing the right thing" and getting good results, they are unlikely to make significant changes. In addition, current ESL and bilingual education teachers are likely to take issue with the language as problem orientation that appears to underlie NCLB, repealing earlier language as right and language as resource orientations in the Bilingual Education Act..

In the final analysis, the added attention paid to the needs of language minority students in the accountability provisions is expected to yield dividends. However, other more academically-oriented provisions and requirements of No Child Left Behind are unlikely to have as much impact on the education of language minority students as proclaimed. Inhibiting factors include the recent backlash against the law from many agents at the institutional level, state departments of education, state legislatures and news media in particular, as well as the differences between what the act prescribes and assumes and practitioners' and researchers' on the ground ("unpeeled") attitudes, beliefs and understandings about what constitutes effective education for language minority students. 
APPENDIX I

Questions asked of participating educators

- What is your evaluation of No Child Left Behind in general and Title III in particular?

- How does No Child Left Behind, in particular Title III,compare with the Bilingual Education Act?

- How has No Child Left Behind affected programs or instruction for English language learners in your school/district/region?

- What are some positive and/or negative features of No Child Left Behind as it pertains to the education English Language Learners?

- One scholar has suggested that there are three orientations toward language, languages and speakers of those languages: language as problem, language as right and language as resource. Which of the orientations do you think best describes the philosophies underlying the Bilingual Education Act and No Child Left Behind?

What other observations or comments do you have about No Child Left Behind as it pertains to your position and educating English language learners? 


\section{REFERENCES}

Baker, Colin (1996). Foundations of bilingual education and bilingualism. Clevedon, UK: Multilingual Matters.

Berliner, David (2002). Educational research: The hardest science of all. Educational Researcher, 3(8), 18-20.

Burnham-Massey, Laurie \& Pina, Marilyn (1990). Effects of reading instruction on English academic achievement of LEP children. Reading Improvement, 27, 129132.

A closer look at scientifically based research - What the words mean (2004). The Journal. Retrieved February 20, 2004, from http://www.thejournal.com/magazine/vault/A4684A.cfm.

Collier, Virginia (1992). A synthesis of studies examining long-term language minority student data on academic achievement. Bilingual Research Journal, 16(1\&2), $187-212$.

Collier, Virginia (1995). Promoting academic success for ESL students. New Jersey: New Jersey Teachers of English to Speakers of Other Languages-Bilingual Educators.

Crawford, James (2002a). "Accountability" versus science in the bilingual education debate. Education Policy Studies Laboratory. Retrieved Feb. 18, 2004 from http://www .asu.edu/educ/epsl/LPRU/features/article3.htm.

Crawford, James (2002b). Obituary: The bilingual education act, 1968-2002. Retrieved Sept. 12, 2003 from http://ourworld.compuserve.com/homepages/ JWCRAWFORD/T7obit.htm. 
Cummins, Jim (1976). The influence of bilingualism on cognitive growth: A synthesis of research findings and explanatory hypotheses. Working Papers on Bilingualism 9, $1-43$.

Cummins, Jim (1979). Cognitive-academic language proficiency, linguistic interdependence, optimal age and some other matters. Working Papers in Bilingualism, 19, 197-205.

Cummins, Jim (1981). Age on arrival and immigrant second language learning in Canada: A reassessment. Applied Linguistics, 11(2), 132-149.

Cummins, Jim (1984). Bilingualism and special education: Issues in assessment and pedagogy. San Diego, CA: College-Hill.

Cummins, Jim (1992). Language proficiency, bilingualism, and academic achievement. In Patricia A. Richard-Amato and Marguerite Ann Snow (Eds), The multicultural classroom. (pp. 16-26).White Plains, NY: Longman.

De La Garza, Jesus Valenzuela \& Medina, Marello (1985). Academic achievement as influenced by bilingual instruction for Spanish-dominant Mexican American children. Hispanic Journal of Behavioral Sciences, 7(3), 247-59.

Erickson, Frederick \& Gutiérrez, Kris (2002). Culture, rigor, and science in educational research. Educational Researcher, 31(8), pp. 21-24.

Hornberger, N. H. (2002). Multilingual language policies and the continua of biliteracy: An ecological approach. Language Policy, 1(1), 27-51. Hornberger, N. H. (Ed.). (2003). Continua of Biliteracy: An Ecological Framework for Educational Policy, Research and Practice in Multilingual Settings (Vol. BEB 41). Clevedon, UK: Multilingual Matters. 
Improving America's Schools Act of 1994. Public Law 103-382 (October 20, 1994) United States Congress.

Krashen, Stephen (1999, May 6). Bilingual education: Arguments for and (bogus) arguments against. Paper presented at the Georgetown University Roundtable on Language and Linguistics. Georgetown: Washington, D.C. Retrieved February 20,2004 http://ourworld.compuserve.com/homepages/JWCRAWFORD/Krashen3.htm.

Krashen, Stephen \& McQuillan, Jeff (1999). Structured immersion falls short of expectations: An analysis of Clark (1999). Retrieved February 21, 2004 from http://ourworld.compuserve.com/homepages/JWCRAWFORD/Krashen5.htm.

Mortensen, Eileen (1984). Reading achievement of native Spanish-speaking elementary students in bilingual vs. monolingual programs. Bilingual Review, 11(3), 31-36.

No Child Left Behind Act of 2001. Public Law 107-110 (January 8, 2002). United States Congress.

Ramirez, J. David, Yuen, Sandra. D. \& Ramey, Dena R. (1991). Final report: Longitudinal study of structured English immersion strategy, early-exit and lateexit programs for language-minority children. Report submitted to the U.S. Department of Education. San Mateo, CA: Aguirre International. Retrieved February 25, 2004 from http://www.ncela.gwu.edu/pubs/ramirez/longitudinal.htm.

Ricento, Thomas K. \& Hornberger, Nancy H. (1996). Unpeeling the onion: language planning and policy and the ELT professional. TESOL Quarterly, 30(3), 401-428.

Ruiz, Richard (1984). Orientations in language planning. NABE Journal, 8, 15-34.

Schiffman, Harold F. (1996). Linguistic Culture and Language Policy. New York: Routledge. 
Thomas, Wayne \& Collier, Virginia (1995). Language minority achievement and program effectiveness. California Association for Bilingual Education Newsletter, $17(5), 19,24$.

Thomas, Wayne \& Collier, Virginia (1996). Language-minority student achievement and program effectiveness. NABE News, 19(6), 33-35.

Thomas, Wayne \& Collier, Virginia (1997). School effectiveness for language minority students. Washington, DC: National Clearinghouse for Bilingual Education.

Toukomaa, Pertti \& Skutnabb-Kangas, Tove (1977). The intensive teaching of the mother tongue to migrant children at pre-school age (Research Report No. 26). Department of Sociology and Social Psychology, University of Tampere.

U.S. Department of Education (2002). Strategic Goal Four: Transform Education into an Evidence-based Field. Washington, D.C.: U.S. Department of Education. Retrieved February 25 from http:/www.ed.gov/about/reports/strat/plan200207/plan.pdf.

U.S. Supreme Court (1974). LAU v. NICHOLS, 414 U.S. 563. Retrieved November 5, 2003 from FindLaw.com http://caselaw.lp.findlaw.com/scripts/getcase.pl? court=us\&vol=414\&invol=563 (para $15 \& 16)$.

Wong Fillmore, Lily (1991). Second language learning in children: A model of language learning in social context. In Ellen Bialystok (Ed), Language processing in bilingual children (pp. 49-66). Cambridge: Cambridge University Press. 